PRZEGLĄD RUSYCYSTYCZNY 2021, nr 3 (175)

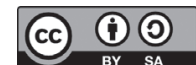

DOI 10.31261/pr.11534

\author{
GABRIELA WILK \\ Uniwersytet Śląski w Katowicach \\ (D) ORCID http://orcid.org/0000-0001-9112-5674
}

\title{
ОСОБЕННОСТИ ПЕРЕВОДА РУССКИХ СУБСТАНДАРТНЫХ ФРАЗЕОЛОГИЗМОВ НА ПОЛЬСКИЙ ЯЗЫК (НА МАТЕРИАЛЕ ПРОИЗВЕДЕНИЙ АЛЕКСАНДРЫ МАРИНИНОЙ)
}

SPECIFICITY OF THE TRANSLATION OF RUSSIAN SUB-STANDARD PHRASEOLOGICAL UNITS INTO POLISH (BASED ON THE WORKS BY ALEXANDRA MARININA)

The article focuses on selected aspects of the translation into Polish of Russian phraseological units that are beyond the linguistic norm. The research material has been excerpted from two Alexandra Marinina's detective novels Requiem and Unwilling Killer and their translations by Alexandra Stronka. The research findings indicate that Stronka most often translates sub-standard phraseological units by means of idioms based on a different image, or lexemes, but these units not frequently differ from the original units in terms of expressive and stylistic colouring.

Keywords: translation, detective novel, Alexandra Marinina, sub-standard phraseological unit

В конце XX столетия как русская, так и польская культура вошли в новую стадию развития, что заметным образом отразилось на литературе, которая, по мнению Марии Черняк, стала одним из каналов массовой коммуникации ${ }^{1}$. Массовая литература, подвергшаяся различным жанровым трансформациям, начала успешно завоевывать читательскую аудиторию.

Обращение к массовому читателю находит свое отражение и в языке современных художественных произведений. Как справедливо замечает Виктория Дидковская, «'массовизация’ языка массовой литературы проявляется в том числе в стремлении

1 М.А. Черняк, Массовая литература XX века, Издательство «Флинта», «Наука», Москва 2007, с. 5 . 
погрузить читателя в стихию живой речи»², благодаря чему он «идентифицирует себя с ее героями не только через предметный мир, но и через мир языка»3. Эти слова полностью можно отнести к языку произведений детективного жанра, которые по объему спроса и предложения занимают в настоящее время весьма существенную позицию на книжном рынке в России и в Польше.

Детектив - жанр неоднородный, в нем можно выделить такие его разновидности, как исторический, иронический, полицейский и др. Независимо от жанрового разнообразия, авторов многих детективных романов объединяет то, что они довольно часто прибегают к применению фразеологизмов. На этот факт обратила внимание Виктория Дидковская, согласно исследованиям которой можно говорить о высокой «плотности» фразеологических единиц в текстах российских детективов ${ }^{4}$. К подобным выводам пришла также Елена Ганапольская, объектом лексикографического описания выбрав именно фразеологизмы, появившиеся на страницах произведений детективного жанра. По ее словам,

Текст детектива насыщен фразеологией. Связано это во многом с тем, что этот жанр ставит своей целью быстрое восприятие книги читателем: читатель должен «проглотить» книгу и купить следующую. Более того, детектив, особенно ряд его современных разновидностей, должен заставить читателя не только мыслить, но и чувствовать. Фразеологизм же, как образная единица с комплексным значением, обладающая при этом высоким эмоционально-экспрессивным потенциалом, помогает достичь обеих названных целей ${ }^{5}$.

В детективных романах широко представлены все стилистические пласты русской фразеологии, встречаются разговорные,

2 В.Г. Дидковская, Окказиональные фразеологизмы в текстах массовой литературы // И. Ю. Третьякова (ред.), Жизнь фразеологии - фразеология в жизни: сборник научных статей к юбилею профессора А.М. Мелерович, Издательство Костромского государственного университета, Кострома 2018, c. 91.

3 Той же, Фразеологизмы в текстах современной массовой литературы // В.И. Макаров (ред.), Фразеологизм в тексте и текст во фразеологизме (Четвертые Жуковские чтения): Материалы Международного научного симпозиума. 4-6 мая 2009 г., НовГУ им. Ярослава Мудрого, Великий Новгород 2009, с. 119.

4 Той же, Окказиональные фразеологизмы..., с. 92.

5 Е.В. Ганапольская, Фразеологический словарь современного российского детектива., т. 1: A-K, Златоуст, Санкт-Петербург 2015, с. 4. 
просторечные, жаргонные и книжные устойчивые обороты. Среди них особо выделяются фразеологизмы, имеющие ярко выраженный просторечный, иногда грубо-просторечный и жаргонный характер, что является проявлением общей тенденции к огрублению и жаргонизации современной речи. По замечанию Василия Химика, подобные единицы можно обнаружить как в детективах, так и в средствах массовой информации, можно их также услышать, идя по улице ${ }^{6}$. В текстах детективного жанра фразеологизмы, находящиеся за пределами литературной нормы, используются, в частности, для передачи экспрессии непринужденной устной речи и речевой характеристики персонажей. Как утверждает Татьяна Сафонова,

Описание приключений героев в России 90-х гг. не мыслится без соответствующей идиоматики - арготических элементов, а также жаргонных, просторечных и грубо-просторечных устойчивых оборотов, появившихся в языке перестроечного и постперестроечного периода7

Одним из современных российских писателей, в произведениях которого встречаются субстандартные фразеологизмы, является Марина Анатольевна Алексеева, пишущая под псевдонимом Александра Маринина. Маринина принадлежит к числу наиболее издаваемых и популярных авторов детективных романов. Недаром ее называют «русской Агатой Кристи», «королевой российского детектива», «чемпионом по тиражам» ${ }^{8}$. Иоланта Любоха-Круглик так пишет о ней:

Początkowo wydawało się, że jest to jedna z licznych autorek, która na chwilę tylko zagości w świadomości czytelników i zniknie w masie podobnych do niej. Czas jednak pokazał, że Marinina miała najwidoczniej do zaproponowania coś, czego nie oferowali inni, bowiem po latach uznawana jest za pisarkę kultową, jeśli w odniesieniu do literatury masowej można użyć takiego określenia9

6 В.В. Химик, Большой словарь русской разговорной экспрессивной речи, Норит, Санкт-Петербург 2004, с. 141.

7 Т. В.Сафонова, Функционирование фразеологических единиц в детективной прозе Б. Акунина, «Вестник Волгоградского государственного университета. Серия 2, Языкознание» 2019, т. 18, № 3, c. 135, https://doi.org/10.15688/ jvolsu2.2019.3.10 (12.11.2020).

8 М.А. Черняк, Массовая литература..., с. 263.

9 J. Lubocha-Kruglik, Powieść kryminalna jako gatunek «zmaccony»: Aleksandra Marinina $w$ polskich przekładach // J. Lubocha-Kruglik, О. Małysa (ред.), Przestrzenie przekładu, т. 2, Wydawnictwo Uniwersytetu Śląskiego, Katowice 2017, c. 100. 
Феномен творчества писательницы отметили также за рубежом, о чем свидетельствуют переводы ее произведений на европейские и азиатские языки, а также научная конференция в Париже, посвященная разным аспектам ее творчества ${ }^{10}$.

Данная статья представляет собой попытку проанализировать способы передачи просторечных и жаргонных фразеологических единиц ${ }^{11}$ в польских переводах двух детективных романов Александры Марининой - Реквием ${ }^{12}$ и Убийца поневоле ${ }^{13}$, выполненных Александрой Стронкой ${ }^{14}$. В процессе анализа мы обратим внимание на случаи расхождения между единицами оригинала и перевода. Из произведения Реквием было выбрано 76 субстандарных фразеологизмов. Данные единицы появляются на страницах романа 89 раз. В детективе Убийца поневоле зарегистрировано 50 субстандартных фразеологизмов и 54 случая их употребления.

Перевод фразеологических единиц можно считать одним из существенных вызовов, которые появляются перед переводчиками. Об их высоком месте в «шкале непереводимости» либо «труднопереводимости» пишут Сергей Влахов и Сидер Фло-

${ }^{10}$ См. Е. И. Трофимова (ред.), Творчество Александры Марининой как отражение современной российской ментальности: Международная конференция, состоявшаяся 19-2о октября 2001 г. Институт славяноведения, Париж, ИНИОН РАН, Москва 2002.

${ }^{11}$ Следует отметить, что иногда сложно дать точную стилистическую характеристику того или иного фразеологизма. Поскольку язык находится в постоянном развитии, границы между просторечием, жаргоном и разговорной разновидностью литературного языка довольно подвижны. Классифицируя тот или иной фразеологизм как субстандартный, мы пользовались пометами в словарях.

12 А. Маринина, Реквием, Эксмо, Москва 2008, http://loveread.me/view_global. php?id=311 (28.09.2020); A. Marinina, Wieczny odpoczynek, przeł. A. Stronka, Czwarta strona, Poznań 2019.

${ }_{13}$ А. Маринина, Убийца поневоле, Эксмо, Москва 2008, http://loveread.ec/ view_global.php?id=2728 (15.10.2020); A. Marinina, Zabójca mimo woli, przeł. A. Stronka, Wydawnictwo W.A.B., Warszawa 2011.

${ }^{14}$ Александра Стронка вписывается в историю переводческой деятельности как переводчик Александры Марининой. Она перевела 20 из 26 ее произведений, до сих пор изданных в Польше (состояние на февраль 2021 г). Однако, помимо романов Марининой, Стронка перевела и отдельные произведения других современных российских писателей - Марины Ахмедовой, Бориса Акунина, Анны и Сергея Литвиновых. См. библиографический указатель переводов в: A. Langowska, Русскоязычная художественная литература в переводах на польский язык (2007-2017 г2.), «Studia Rossica Gedanensia» 2018, № 5, c. 416-435, https://doi.org/10.26881/srg.2018.5.25 (11.11.2020). 
рин ${ }^{15}$. В качестве «языковой проблемы перевода» ${ }^{16}$ воспринимает их также Кшиштоф Хейвовски. Передача иностранному читателю субстандартных элементов языка оригинала в силу как лингвистических, так и экстралингвистических причин также является непростой, что подтверждают исследования Романа Левицкого ${ }^{17}$. Согласно Людмиле Степановой, «Переводчики современной русской литературы все чаще сталкиваются, наряду с традиционными трудностями (переводом реалий, фразеологизмов, игры слов и т.п.), с новым 'крепким орешком' - переводом жаргонизмов» ${ }^{18}$. Еще более сложной задачей оказывается перевод жаргонной фразеологии или других ее разновидностей, находящихся за переделами литературной нормы.

Как известно, существуют два основных способа перевода устойчивых оборотов - фразеологический и нефразеологический. Фразеологический перевод заключается в подборе для исходного выражения устойчивой единицы, при этом фразеологизмы языка оригинала и перевода могут находиться в разной степени близости. Кшиштоф Хейвовски называет шесть основных техник перевода идиом, три из которых можем отнести к фразеологическому переводу: использование идиомы, аналогичной по форме и по смыслу, использование идиомы, отличающейся по форме, но аналогичной по смыслу, образование в языке перевода «новой идиомы», являющейся, напр., контаминацией двух выражений (последняя техника довольно редко применяется) $)^{19}$.

Рассмотрим способы передачи на польский язык русских субстандартных фразеологизмов, обнаруженных нами в произведениях Марининой. Первый отрывок иллюстрирует эквивалентный перевод фразеологической единицы:

${ }_{15}$ С. Влахов, С. Флорин, Непереводимое в переводе, Международные отношения, Москва 1980, с. 179.

${ }^{16}$ K. Hejwowski, Kognitywno-komunikacyjna teoria przekładu, Wydawnictwo Naukowe PWN, Warszawa 2004, c. 108-112.

${ }^{17}$ Cм. R. Lewicki, Przekład wobec zjawisk podstandardowych. Na materiale polskich przekładów współczesnej prozy rosyjskiej, UMCS, Lublin 1986.

${ }^{18}$ L. Stěpanova, Фразеологизмы в современных русских детективных романах и проблемы их перевода на чешский язык // W. Chlebda (ред.), Frazeologia a przekład, Wydawnictwo Uniwersytetu Opolskiego, Opole 2014, c. 138.

${ }^{19} \mathrm{~K}$. Hejwowski, Iluzja przekładu. Przekładoznawstwo w ujęciu konstruktywnym, Stowarzyszenie Inicjatyw Wydawniczych-Śląsk Wydawnictwo Naukowe, Katowice 2015, c. 253. 
Он подобрал пятнадцатилетнего грязного бродяжку с иконописными глазами и удивительным артистическим даром, вытащил его из дерьма, оставил жить в своей квартире, потому что разглядел в нем уникальный талант, такой талант, какого был лишен он сам ${ }^{20}$.

Zaopiekował się piętnastoletnim brudnym włóczęgą z uduchowionymi oczami i niezwykłymi zdolnościami, wyciągnął go z gówna i pozwolił zamieszkać u siebie, bo dostrzegł w nim wyjątkowy talent, taki, jakiego jemu zabrakło ${ }^{21}$.

Русский вульгарно-просторечный фразеологизм «вытащить/ вытаскивать из дерьма кого» имеет значение 'выручить кого-л., помочь выйти из крайне неприятной ситуации, избавить от тяжелых, унизительных условий существования'22. Хотя польские словари не фиксируют выражения «wyciągnąć kogoś z gówna», оно обладает признаками устойчивости, а само слово "gówno» (как и «дерьмо») используется в значении 'skomplikowana, nieprzyjemna, niekorzystna sytuacja'23. В данном случае сохраняется образная основа русской единицы. Оба выражения имеют одинаковую семантику, компонентный состав и функциональностилистические особенности.

Ввиду отсутствия полного эквивалента той или иной субстандартной фразеологической единицы в польском языке Александра Стронка довольно часто прибегает к подбору фразеологизма, основанного на ином образе. Для примера:

- Куплю жратвы побольше да повкусней, отвезу ей, а то вечно она жалуется, что я ей не помогаю. Послушать ее, так у нее, кроме меня, и детей больше нет, а Люська с Генкой уж и не в счет. Конечно, они - сиротинушки, а я богатенький Буратино, должен всех их содержать 24.

- Kupię dużo smacznego żarcia, zawiozę jej, bo wiecznie narzeka, że nie pomagam. Gdyby jej posłuchać, można by pomyśleć, że oprócz mnie nie ma więcej dzieci, a Luśka i Gienka w ogóle się nie liczą. Według niej to biedne sierotki, a ja jestem przy forsie, więc wszystkich mam utrzymywać ${ }^{25}$.

\footnotetext{
${ }^{20}$ А. Маринина, Реквием...

${ }^{21}$ A. Marinina, Wieczny odpoczynek..., c. 92.

${ }^{22}$ В.В. Химик, Большой словаръ..., с. 141.

${ }^{23}$ M. Czeszewski, Stownik polszczyzny potocznej, Wydawnictwo Naukowe PWN, Warszawa 2006, c. 107.

${ }^{24}$ А. Маринина, Убийца...

${ }^{25}$ A. Marinina, Zabójca..., c. 161-162.
} 
Фразеологизм «богатенький Буратино» используется для характеристики богача, человека при деньгах ${ }^{26}$. Он появился в молодежном жаргоне, однако со временем круг его употребления стал шире. Согласно Валерию Мокиенко, в настоящее время данная единица обозначает «как состоятельного бизнесмена, предпринимателя в постсоветской России, так и человека, располагающего средствами в условиях, когда у окружающих либо денег нет совсем, либо их гораздо меньше» ${ }^{27}$. Устойчивый оборот «богатенький Буратино» принадлежит к национально-маркированным единицам, это фраза, с которой хитрая Лиса обращается к главному герою советского фильма «Приключения Буратино» по мотивам сказки Алексея Толстого 28 . Поскольку этот фразеологизм не имеет своего эквивалента в польском, переводчица решила подобрать его фразеологический аналог ${ }^{29}$ - «być przy forsie», который используется в разговорной речи и обозначает, что человек имеет много денег ${ }^{30}$. Данное переводческое решение можно считать удачным.

В следующем примере семантика фразеологизмов отличается в текстах оригинала и перевода:

- Тебе нужно жениться, Игорь.

- Щас, шнурки поглажу и в загс побегу, - фыркнул Вильданов. - Ты что, совсем охренел, старик? ${ }^{31}$

- Musisz się ożenić.

- Już pędzę na złamanie karku do urzędu - prychnął Wildanow. - Upadłeś na głowę, stary? ${ }^{32}$

${ }^{26}$ С.И. Левикова, Большой словарь молодежного сленга, ФИАР-ПРЕСС, Москва 2003, с. 554.

${ }_{27}$ В.М. Мокиенко, Современная славянская неофразеология: сходства и различия // Е.В. Ничипорчик (гл. ред.) [и др.], Славянские лингвокультуры в пространственном и временном континууме, ГГУ им. Ф. Скорины, Гомель 2019, с. 139.

28 Там же, с. 140.

29 Под термином «фразеологические аналоги» мы понимаем, вслед за Анатолием Барановым и Дмитрием Добровольским, единицы, характеризующиеся «семантическим сходством при (почти) полном отсутствии формального сходства, т.е. сходства синтаксической структуры и компонентного состава». А. Н. Баранов, Д. О. Добровольский, Основы фразеологии, Издательство «Флинта», «Наука», Москва 2013, с. 206.

${ }^{30}$ M. Bańko, Inny stownik języka polskiego. T. 1: $a$-ó, Wydawnictwo Naukowe PWN, Warszawa 2000, c. 417.

${ }^{31}$ А. Маринина, Реквием...

${ }^{32}$ A. Marinina, Wieczny odpoczynek..., c. 191. 
Фразеологизм «сейчас, только шнурки поглажу» используется в значении 'нет, как бы не так, вон чего захотел'з3. Глажка шнурков, вне всякого сомнения, является бесполезным и лишенным смысла занятием. Польская единица «pędzić (biec, gnać, uciekać itp.) na złamanie karku» обозначает 'biec, uciekać itp. bardzo szybko, co tchu, w wielkim pośpiechu, nie zwracając uwagi na przeszkody i niebezpieczeństwo'34, и, тем самым, в ее семантике нет признака бессмысленности, она не выражает также отказа. В приведенном контексте польский фразеологизм предполагает иронию, в связи с чем его можно считать близким по значению к русскому. Обе единицы отличаются стилистической окраской.

Еще один пример перевода устойчивого оборота находим в следующем фрагменте:

- Тогда пусть не жалуется, - шепотом отрезала Настя. - Или крутить роман, или не ездить на дачу. Одно из двух. Давай послушаем, сейчас Мурашов нам мозги прочищать будет.

На трибуну поднялся Анатолий Николаевич Мурашов, один из помощников начальника управления. Его коньком была дисциплина [... ${ }^{35}$.

- No to niech się nie skarży - szeptem ucięła Nastia. - Albo romansuje, albo nie jeździ na daczę. Jedno z dwojga. Posłuchajmy, jak Muraszow będzie nas teraz rozstawiać po kątach.

Na mównicę wszedł Anatolij Nikołajewicz Muraszow, jeden z zastępców naczelnika wydziału. Jego konikiem była dyscyplina $[\ldots]^{36}$.

Для жаргонного фразеологизма «прочищать мозги» 'наказывать, избивать, обругивать кого-л. ${ }^{37}$ переводчица подобрала разговорный фразеологизм «rozstawiać kogoś po kątach» 'narzucać komuś swoją wolę, rządzić, komendować kimś'” ${ }^{8}$. Следует отметить, что данные единицы не совпадают ни по значению, ни по стилистической окраске. Тем не менее, поскольку исходный оборот относится к человеку, который любит дисциплину, его перевод-

33 В.С. Елистратов, Толковый словарь русского сленга, АСТ-Пресс Книга, Москва 2005, с. 368. В романе используется просторечная форма «щас» вместо «сейчас». Она отражает произношение слова в живой речи (в данном случае мы имеем дело с упрощением групп согласных).

${ }^{34}$ A. Kłosińska, E. Sobol, A. Stankiewicz, Wielki słownik frazeologiczny PWN z przystowiami, PWN, Warszawa 2005, c. 224.

35 А. Маринина, Убийца...

${ }^{36}$ A. Marinina, Zabójca..., c. 265.

37 В.С. Елистратов, Толковый словарь..., с. 334.

${ }^{38}$ A. Kłosińska, E. Sobol, A. Stankiewicz, Wielki słownik..., c. 164. 


\section{ОСОБЕННОСТИ ПЕРЕВОДА...}

ческое соответствие в определенной степени передает смысл оригинала.

В следующем примере встречается устойчивое словосочетание «на фиг» с явно выраженным грубым оттенком. Оно используется в значении 'вон, прочь, долой, в неопределенное место, куда угодно'39. В русском языке существует также выражение «иди (пошёл, катись) [ты] на фиг».

Повыступаешь один, без моей помощи, пару месяцев, а потом знаешь, что с тобой будет? Не знаешь? Так я тебе скажу. Тебе дадут в руки барабан и палочки и поставят во главе колонны артистов, идущих на фиг. Радует тебя такая перспектива?

Мысль была сложной, Игорь ее не понял. Какая колонна? Почему на фиг? И при чем тут барабан и палочки? Впрочем, говорят, что лучшая оборона - это нападение ${ }^{40}$.

Powystępujesz sobie bez mojej pomocy przez parę miesięcy, a potem wiesz, co się stanie? Nie wiesz? To c powiem. Dostaniesz bębenek i pałeczki i staniesz na czele kolumny artystów maszerujących w siną dal. Cieszy cię ta perspektywa?

Myśl była trudna, Igor jej nie zrozumiał. Jaka kolumna? Dlaczego w siną dal? I co ma z tym wspólnego bębenek i pałeczki? No cóż, podobno najlepszą obroną jest atak ${ }^{41}$.

Александра Стронка использовала здесь прием структурносемантической трансформации традиционного польского выражения «pójść, odejść itp. w siną dal» 'pójść, odejść itp. bez jasno określonego celu, zwykle na zawsze'42. Не удалось ей сохранить эмоциональной и стилистической нагрузки исходного фразеологизма, - в польской единице отсутствует оттенок грубости, и она воспринимается как литературная.

К техникам нефразеологического перевода можно отнести, вслед за Хейвовским, передачу фразеологической единицы с помощью слова либо неидиоматического выражения, а также буквальный перевод ${ }^{43}$. В детективе Реквием находим такой фрагмент:

Соседка в гости приходила, трехлетнего малыша с собой привела, а я в этот печальный момент в ванной отмокал после суточного дежурства. Очки-то

${ }^{39}$ В.В. Химик, Большой словарь..., с. 141.

${ }^{40}$ А. Маринина, Реквием...

${ }^{41}$ A. Marinina, Wieczny odpoczynek..., c. 327-328.

${ }^{42}$ A. Kłosińska, E. Sobol, A. Stankiewicz, Wielki stownik..., c. 476.

${ }^{43}$ K. Hejwowski, Iluzja przekładu..., c. 253. 
я на диване оставил, вместе с газеткой, которую перед тем читал. Ну вот, я в ванной кайф ловлю, а ребеночек тоже свой кайф ловит, мои очки ломаючи. Жена с соседкой языками зацепились и радуются, что пацан не плачет ${ }^{44}$.

Niedawno odwiedziła nas sąsiadka z trzyletnim brzdącem. Akurat moczyłem się $\mathrm{w}$ wannie po dwudziestoczterogodzinnym dyżurze. Okulary zostawiłem na kanapie, razem z gazetą, którą wcześniej czytałem. No więc relaksuję się w wannie, a tymczasem berbeć też się relaksuje, niszcząc moje okulary. Żona z sąsiadką gadają jak najęte i cieszą się, że smarkacz nie płacze ${ }^{45}$.

В оригинале встречается широко известный фразеологизм молодежного жаргона «ловить кайф», базирующийся на заимствованном из арабского языка слове «кайф». Данный фразеологизм синонимичен лексеме «кайфовать» и имеет несколько значений: 1) 'находиться в состоянии наркотического или алкогольного опьянения'; 2) 'получать удовольствие от чего-либо, блаженствовать'; 3) 'пребывать в приятно расслабленном, отрешенном состоянии'; 4) 'переживать приятные чувства, испытывать положительные эмоции'; 5) 'напиваться пьяным’46. Русскую фразеологическую единицу переводчица передала нейтральным польским глаголом «relaksować się» 'pozbywać się zmęczenia, znużenia lub stresu, robiąc to, co się lubi, albo nie robiąc nic'47. При том, что в оригинале можно было бы без особых смысловых и стилистических потерь заменить фразеологизм указанным словом, в переводе эти потери оказались весьма значительны. В связи с чем такой перевод трудно считать полноценным. В контексте сказанного стоит привести слова польской исследовательницы Божены Реяковой, касающиеся подобных замен в переводе:

Jeżeli jednostki dadzą się wymieniać ze względu na wartości semantyczne, cierpią na tym ich inne właściwości [...], a więc określona wartość stylistyczna ${ }^{48}$.

Александра Стронка прибегла к замене фразеологической единицы лексической, видимо, потому, что в польском языке

44 А. Маринина, Реквием...

45 A. Marinina, Wieczny odpoczynek..., c. 273.

${ }^{46}$ С. И. Левикова, Большой словарь..., с. 623.

${ }^{47}$ P. Żmigrodzki (ред.), Wielki stownik języka polskiego, https://www.wsjp.pl/ index.php?id_hasla=13732\&ind=0\&w_szukaj=relaksowa\%C4\%87+si\%C4\%99+ (5.11.2020).

${ }^{48} \mathrm{~B}$. Rejakowa, Mechanizmy językowe $w$ przekładzie związków frazeologicznych na materiale języka polskiego i słowackiego, UMCS, Lublin 1994, c. 51. 


\section{ОСОБЕННОСТИ ПЕРЕВОДА...}

нелегко найти соответствие выражению «кайф ловить"49 в таком значении, в котором оно используется Марининой (2, 3, 4 значения по словарю). Состояние эйфории под воздействием наркотических средств или спиртных напитков (1 значение) можно было бы, в свою очередь, передать выражением «mieć odlot (jazdę, fazę)».

В рассмотренном примере русский жаргонный фразеологизм был передан на польский язык при помощи нейтрального слова. В ходе анализа языкового материала мы нашли и такие фрагменты, в которых субстандартная фразеологическая единица переводится экспрессивно-оценочным словом:

Я отрыл эту книжку в библиотеке, когда мотал срок за грабеж ${ }^{50}$.

Wyszperałem tę książkę w bibliotece w czasie odsiadki za rozbój ${ }^{51}$.

В уголовном жаргоне «мотать срок» означает 'отбывать срок заключения по приговору суда'52. Лексема «odsiadka» обладает сходным значением ('odbywanie kary więzienia'53), однако она отличается менее сниженной стилистической окраской.

В некоторых случаях перевод субстандартного фразеологизма производится с помощью экспрессивно-оценочного слова, имеющего другое значение по сравнению с единицей оригинала:

Она, видно, та еще штучка, три недели ангелом прикидывалась, а они conли распустили, бдительность потеряли, и вот, пожалуйста ${ }^{54}$.

49 В других детективных романах Марининой Стронка переводит фразеологизм кай ловить иначе, напр.: «По-моему, она от этого особый кай ф лов ила» (Светлый лик смерти) - «Moim zdaniem czerpała z tego wyjątkową przyjemność» (Jasne oblicze śmierci); «- Разорилась, - призналась она. - Зато кайф поймала. Ведь в чем вся прелесть-то? Толстая, неуклюжая баба - и предъявляет обвинение самому Алояну» (Черный список) - «Zrujnowała - przyznała. Ale to był kompletny odjazd. Miałam frajdę, że gruba niezgrabna baba potrafiła oskarżyć samego Ałojana» (Czarna lista). Способы передачи того или иного устойчивого оборота в разных произведениях российской писательницы заслуживают отдельного рассмотрения.

${ }_{50}$ А. Маринина, Убийца...

${ }^{51}$ A. Marinina, Zabójca..., c. 81-82.

52 З.М. Зугумов, Русскоязычный жаргон. Историко-этимологический толковый словарь преступного мира, Книжный мир, Москва 2018, с. 361.

${ }_{53}$ M. Bańko, Inny stownik..., c. 1125.

54 А. Маринина, Убийца... 
Niezła z niej cwaniara, przez trzy tygodnie udawała niewiniątko, a oni się ca ckali, stracili czuja, no i proszę̧5.

Грубо-просторечный устойчивый оборот «сопли распустить» функционирует в значении 'начать хныкать, ныть; проявить малодушие 56 . В свою очередь, польский разговорный глагол «cackać się» обозначает "postępować z osobą lub rzeczą zbyt delikatnie, ostrożnie i powoli' ${ }^{57}$. В данном случае нет оснований говорить не только о сходстве в семантике сопоставляемых единиц, но и о подобной эмоционально-экспрессивной окраске.

Стоит еще отметить, что в приведенном отрывке нейтральное устойчивое словосочетание «бдительность потерять» было переведено при помощи жаргонного «stracić czuja» с аналогичным значением.

К нефразеологическому переводу, как было сказано, можно отнести также буквальный перевод, который нередко считается примером переводческой неудачи. Рассмотрим следующий фрагмент:

- Ага, пей, пей, - спокойно заметил Вячеслав Олегович. - Продемонстрируй мне, какой ты взрослый. А то я-то не знаю, все думаю, что ты маленький еще, на горшок тебя за ручку вожу, с шантажистом твоим разбираться собрался, прессу тебе готовлю к концерту. А ты у нас, оказывается, большой, все знаешь и сам умеешь. Валяй, Игорь, вперед и с песнями. Флаг только в руки не забудь ${ }^{5}$.

- Uhm, pij sobie, pij - zauważył Wiaczesław Olegowicz spokojnie. - Pokaż mi, jaki jesteś dorosły. Bo nie wiem i wciąż myślę, że jesteś jeszcze dzieckiem, sadzam cię na nocnik, zamierzam rozprawić się z twoim szantażystą, przygotowuję ci prasę przed koncertem. A tymczasem okazuje się, że jesteś już duży, wszystko wiesz i potrafisz. No to dalej, Igorze, do boju. Tylko nie zapomnij wziąć flagi do ręki ${ }^{59}$.

Переводчица восприняла сочетание слов «флаг в руки» как свободное, а не устойчивое. В то время как это жаргонный фразеологизм, имеющий иронический оттенок и обозначающий 'напутствие, пожелание: делай что хочешь, как считаешь нужным;

${ }^{55}$ A. Marinina, Zabójca..., c. 120.

${ }^{56}$ Д.И. Квеселевич, Толковый словарь ненормативной лексики русского языка, Астрель, АСТ, Москва 2005, с. 801.

${ }^{57}$ M. Bańko, Inny stownik..., c. 147.

${ }^{8}$ А. Маринина, Реквием...

${ }^{59}$ A. Marinina, Wieczny odpoczynek..., c. 327. 


\section{ОСОБЕННОСТИ ПЕРЕВОДА...}

пусть делает, что хочет ${ }^{\prime 60}$ (он также имеет свое продолжение «барабан на шею, ветер в спину», а слово «флаг» можно заменить на «знамя»). Отчасти синонимичным ему был бы устойчивый оборот «скатертью дорога (дорожка)». То, что в детективном романе Реквием мы имеем дело с нестандартным употреблением фразеологической единицы (она выступает средством языковой игры), усложнило задачу переводчице. Можно было бы использовать в этом случае польское выражение «krzyżyk (krzyż) na drogę», которое употребляется с тем, чтобы сообщить комуто, что говорящий не будет переживать расставания с кем-то ${ }^{61}$.

Стоит также обратить внимание на предложение «Валяй, Игорь, вперед и с песнями», представляющее собой пример языковой игры. Здесь появляется преобразованный фразеологизм «вперед и с песней (песнями)» 'давай, ну же, пошли, айда!'62. Его можно воспринять и буквально, поскольку Игорь - певец. Призыв к действию Александра Стронка передала при помощи сочетания «do boju», что можно считать оправданным, однако сохранить языковую игру ей не удалось.

В следующем примере фразеологизм с оттенком грубости «заткни фонтан» 'замолчи'63, представляющий собой сокращение афоризмов Козьмы Пруткова «Если у тебя есть фонтан, заткни его; дай отдохнуть и фонтану», «Заткни фонтан красноречия, зане и фонтан отдохнуть должен» ${ }^{64}$, в польском переводе опускается:

- Заткни фонтан, а то все мысли из башки выльются, - мрачно пообещал Костыря, - их там у тебя и так не густо ${ }^{65}$.

- Zaraz zapomnisz, jak się nazywasz - posępnie obiecał Kostyria - a gębę Ci tak przemaluję, że rodzona matka cię nie pozna ${ }^{66}$.

Опущение, согласно Кшиштофу Хейвовскому, является очередной техникой перевода идиом ${ }^{67}$. Как утверждают Анатолий Баранов и Дмитрий Добровольский:

${ }^{60}$ В. В. Химик, Большой словарь..., с. 655.

${ }^{61}$ P. Żmigrodzki (ред.), Wielki stownik..., https://wsjp.pl/index.php?id_hasla=1701 (13.11.2020).

${ }^{62}$ В.С. Елистратов, Толковый словарь..., с. 149.

63 Там же..., с. 71.

${ }^{64}$ В. В. Химик, Большой словаръ..., с. 656.

${ }^{65}$ А. Маринина, Убийца...

${ }^{66}$ A. Marinina, Zabójca..., c. 121.

${ }^{67}$ K. Hejwowski, Iluzja przekładu..., c. 253, 272-273. 
[...] особенности индивидуального стиля автора, которые хороший перевод должен сохранять, не обязательно привязаны к конкретным фразеологизмам. Гораздо более значимыми с этой точки зрения оказываются авторские метафоры, стилистическая окраска текста, ритмические характеристики фразы и т.п. ${ }^{68}$.

Приведенные слова российских ученых в какой-то степени объясняют решение переводчика. В качестве соответствия для «заткни фонтан» Стронка не использовала польские фразеологизмы с подобным оттенком грубости (типа «stul gębę (mordę, pysk)»), вместо этого она выбрала прием опущения, стараясь, однако, сохранить стилистическую окраску оригинального текста. С этой целью она прибегла к семантической трансформации, воспользовавшись фразеологизмом, имеющим грубовато-сниженный оттенок «sprać (stłuc, zbić) kogoś tak, że rodzona matka go nie pozna», и подвергнув его компонентной замене.

На основании проанализированных примеров, выбранных нами из двух детективных романов Марининой Реквием и Убийца поневоле, можно заметить, что Александра Стронка довольно часто переводила русский фразеологизм при помощи польского, однако основанного на другом образе. Не всегда удавалось ей полностью сохранить и смысл, и экспрессию, и стилистическую окраску переводимой субстандартной фразеологической единицы. Вместо фразеологизмов в оригинале переводчица использовала также отдельные слова. Независимо от того, осуществлялся фразеологический либо нефразеологический перевод, устойчивые обороты, находящиеся за пределами литературной нормы, нередко передавались ею при помощи единиц менее сниженных и даже нейтральных.

Анализ романа Реквием показал, что в 56 случаях из 89 переводчица применяла фразеологический перевод, в $33-$ нефразеологический. Что касается детектива Убийца поневоле, то в 37 случаях из 54 просторечные и жаргонные фразеологизмы она переводила, используя устойчивые выражения, в 17 случаях с помощью лексических единиц. Эти количественные данные

${ }^{68}$ А. Н. Баранов, Д. О. Добровольский, Основы фразеологии..., с. 212. 
свидетельствуют о том, что тексты перевода в меньшей степени насыщены субстандартными фразеологизмами.

Стоит отметить, что Александра Стронка применяла также прием опущения фразеологизма при компенсации его экспрессивно-стилистической окраски за счет других средств выразительности. В некоторых случаях для того, чтобы сохранить образность и оценочность авторского оригинала, она старалась также нейтральную русскую единицу передавать жаргонной, компенсируя, таким образом, потери. К примеру, «бдительность потерять» было переведено с помощью «stracić czuja». Похожих случаев в детективе Реквием выявлено 8, в детективе Убийца поневоле - 3. Если посмотреть на весь текст, а не на отдельные его фрагменты, то следует обратить внимание на то, что русским нейтральным либо разговорным словам в обоих детективных романах Стронка иногда подбирала более сниженные польские соответствия, что также в некоторой степени компенсирует отсутствие в переводе субстандартных фразеологизмов (напр., слово «молодец» было переведено при помощи «spoko gość», «ладно, не ори» - «wyluzuj, stary», «выпить» - «golnąć»). Как справедливо отмечает Роман Левицки,

Właśnie stylistyczne znaczenia jednostek tekstu najczęściej są przekazywane $\mathrm{z}$ wykorzystaniem kompensacji. Dzieje się tak dlatego, że stylistyczny charakter tekstu przysługuje mu jako całości, lecz jest realizowany dzięki odpowiedniemu nacechowaniu stylistycznemu konkretnych jego jednostek. W przekładzie mogą to być jednostki inne, tj. nierównoległe ${ }^{69}$.

В силу формальных ограничений в настоящей статье мы сосредоточились лишь на некоторых аспектах перевода субстандартных фразеологизмов в выбранных нами романах российской писательницы и их польских переводах. Предлагаемое рассмотрение открывает, как нам кажется, перспективы для дальнейших исследований способов подобного перевода на польский русской просторечной и жаргонной фразеологии, характерной для произведений детективного жанра не только Александры Марининой.

${ }^{69}$ R. Lewicki, Zagadnienia lingwistyki przekładu, Wydawnictwo UMCS, Lublin 2017, c. 225. 


\section{REFERENCES}

Bańko, Mirosław. Inny stownik języka polskiego. Warszawa: Wydawnictwo Naukowe PWN, 2000.

Baranov, Anatoliy N., Dobrovol'skiy, Dmitriy O. Osnovy frazeologii. Moskva: Izdatel'stvo "Flinta", "Nauka”, 2013 [Баранов, Анатолий Н., Добровольский, Дмитрий О. Основы фразеологии. Москва: Издательство “Флинта”, “Наука”, 2013].

Chernyak, Mariya A. Massovaya literatura XX veka. Moskva: Izdatel'stvo "Flinta", "Nauka”, 2007 [Черняк, Мария. А. Массовая литература XX века. Москва: Издательство “Флинта”, “Наука”, 2007].

Czeszewski, Maciej. Stownik polszczyzny potocznej. Warszawa: Wydawnictwo Naukowe PWN, 2006.

Didkovskaya, Viktoriya G. "Frazeologizmy v tekstakh sovremennoy massovoy literatury." Frazeologizm v tekste i tekst vo frazeologizme (Chetvertyyezhukovskiye chteniya): Materialy Mezhdunarodnogo nauchnogo simpoziuma. 4-6 maya 2009 g. Ed. Makarov, Vladlen I. 118-121. Velikiy Novgorod: NovGU im. Yaroslava Mudrogo, 2009 [Дидковская, Виктория Г. “Фразеологизмы в текстах современной массовой литературы.” Фразеологизм в тексте и текст во фразеологизме (Четвертые Жуковские чтения): Материалы Международного научного симпозиума. 4-6 мая 2009 г. Ред. Макаров, Владлен И. 118-121. Великий Новгород: НовГУ им. Ярослава Мудрого, 2009].

Didkovskaya, Viktoriya G. “Okkazional'nyye frazeologizmy v tekstakh massovoy literatury." Zhizn' frazeologii - frazeologiya $v$ zhizni: sborniknauchnykh statey $k$ yubileyu professora A.M. Melerovich. Ed. Tret'yakova, Irina Yu. Kostroma: Izdatel'stvo Kostromskogo gosudarstvennogo universiteta, 2018: 89-98. [Дидковская, Виктория Г. “Окказиональные фразеологизмы в текстах массовой литературы.” Жизнь фразеологии - фразеология в жизни: сборник научных статей к юбилею профессора А.М. Мелерович. Ред. Третьякова, Ирина Ю. Кострома, Издательство Костромского государственного университета, 2018: 89-98.].

Ganapol'skaya, Yelena V. Frazeologicheskiy slovar' sovremennogo rossiyskogo detektiva: V 2 t. T. 1: A-K. Sankt-Peterburg: Zlatoust, 2015 [Ганапольская, Елена В. Фразеологический словарь современного российского детектива: В 2 m. Т. 1: A-К. Санкт-Петербург: Златоуст, 2015].

Hejwowski, Krzysztof. Iluzja przekładu. Przekładoznawstwo w ujęciu konstruktywnym. Katowice: Stowarzyszenie Inicjatyw Wydawniczych-Śląsk Wydawnictwo Naukowe, 2015.

Hejwowski, Krzysztof. Kognitywno-komunikacyjna teoria przekładu. Warszawa: Wydawnictwo Naukowe PWN, 2004.

Khimik, Vasiliy V. Bol'shoy slovar' russkoy razgovornoy ekspressivnoy rechi. Sankt-Peterburg: Norit, 2004 [Химик, Василий. В. Большой словарь русской разговорной экспрессивной речи. Санкт-Петербург: Норит, 2004].

Kłosińska, Anna, Sobol, Elżbieta, Stankiewicz, Anna. Wielki stownik frazeologiczny PWN z przystowiami. Warszawa: Wydawnictwo PWN, 2005.

Kveselevich, Dmitriy I. Tolkovyy slovar' nenormativnoy leksiki russkogo yazyka. Moskva: Astrel', AST, 2005 [Квеселевич, Дмитрий И. Толковый словарь ненормативной лексики русского языка. Москва: Астрель, АСТ, 2005]. 


\section{ОСОБЕННОСТИ ПЕРЕВОДА...}

Langowska, Agnieszka. "Russkoyazychnaya khudozhestvennaya literatura v perevodakh na pol'skiy yazyk (2007-2017 gg.).” Studia Rossica Gedanensia, no. 5, 2018: 410-435 <https://doi.org/10.26881/srg.2018.5.25> [Langowska, Agnieszka. "Русскоязычная художественная литература в переводах на польский язык (2007-2017 гг.).” Studia Rossica Gedanensia, no. 5, 2018: 410-435 <https:// doi.org/10.26881/srg.2018.5.25>].

Levikova, Svetlana I. Bol'shoy slovar' molodezhnogo slenga. Moskva: FIAR-PRESS, 2003 [Левикова, Светлана И. Большой словарь молодежного сленга. Москва: ФИАР-ПРЕСС, 2003].

Lewicki, Roman. Przekład wobec zjawisk podstandardowych. Na materiale polskich przekładów współczesnej prozy rosyjskiej. Lublin: UMCS, 1986.

Lewicki, Roman. Zagadnienia lingwistyki przekładu. Lublin: Wydawnictwo UMCS, 2017.

Lubocha-Kruglik, Jolanta. "Powieść kryminalna jako gatunek 'zmącony': Aleksandra Marinina w polskich przekładach.” Przestrzenie przekładu. T. 2. Ed. Lubocha-Kruglik, Jolanta, Małysa, Oksana. Katowice: Wydawnictwo Uniwersytetu Śląskiego, 2017: 99-110.

Marinina, Aleksandra. Rekviyem. Moskva: Eksmo, $2008<$ http://loveread.me/ view_global.php?id=311> [Маринина, Александра. Реквием. Москва: Эксмо, $2008<$ http://loveread.me/view_global.php?id=311>].

Marinina, Aleksandra. Ubiytsa ponevole. Moskva: Eksmo, $2008<\mathrm{http}$ ://loveread. ec/view_global.php?id=2728> [Маринина, Александра. Убийца поневоле. Москва: Эксмо, 2008 <http://loveread.ec/view_global.php?id=2728>].

Marinina, Aleksandra. Wieczny odpoczynek. Transl. Stronka, Aleksandra. Poznań: Czwarta strona, 2019.

Marinina, Aleksandra. Zabójca mimo woli. Transl. Stronka, Aleksandra. Warszawa: Wydawnictwo W.A.B., 2011.

Mokiyenko, Valeriy M. "Sovremennaya slavyanskaya neofrazeologiya: skhodstva i razlichiya." Slavyanskiye lingvokul'tury $v$ prostranstvennom i vremennom kontinuume. Ed. Nichiporchik, Yelena V. et al. Gomel': GGU im. F. Skoriny, 2019: 137146. [Мокиенко, Валерий М. "Современная славянская неофразеология: сходства и различия.” Славянские лингвокультуры в пространственном и временном континууме. Ред. Ничипорчик, Елена В. и др. Гомель: ГГУ им. Ф. Скорины, 2019: 137-146.].

Rejakowa, Bożena. Mechanizmy językowe w przekładzie związków frazeologicznych na materiale języka polskiego i słowackiego. Lublin: UMCS, 1994.

Safonova, Tat'yana V. "Funktsionirovaniye frazeologicheskikh yedinits v detektivnoy proze B. Akunina." Vestnik Volgogradskogo gosudarstvennogo universiteta. Seriya 2, Yazykoznaniye, t. 18, no. 3, 2019: 130-139 <https:// doi.org/10.15688/jvolsu2.2019.3.10> [Сафонова, Татьяна В. "Функционирование фразеологических единиц в детективной прозе Б. Акунина.” Вестник Волгоградского государственного университета. Серия 2, Языкознание, т. 18, № 3, 2019: 130-139 <https://doi.org/10.15688/jvolsu2.2019.3.10>].

Stěpanova, Ludmila. "Frazeologizmy v sovremennykhrusskikh detektivnykh romanakh i problemy ikh perevoda na cheshskiy yazyk” [“Фразеологизмы в современных русских детективных романах и проблемы их перевода на чешский язык”] Frazeologia a przektad. Ed. Chlebda, Wojciech. Opole: Wydawnictwo Uniwersytetu Opolskiego, 2014: 133-139. 


\section{GABRIELA WILK}

Trofimova, Yelena I. Ed. Tvorchestvo Aleksandry Marininoy kak otrazheniye sovremennoy rossiyskoy mental'nosti: Mezhdunarodnaya konferentsiya, sostoyavshayasya 19-20 oktyabrya $2001 \mathrm{~g}$. Institut slavyanovedeniya, Parizh. Moskva: INION RAN, 2002 [Трофимова, Елена И., Ред. Творчество Александры Марининой как отражение современной российской ментальности: Международная конференция, состоявшаяся 19-2о октября 2001 г. Институт славяноведения, Париж. Москва: ИНИОН РАН, 2002].

Vlakhov, Sergey, Florin, Sider. Neperevodimoye $v$ perevode. Moskva: Mezhdunarodnyye otnosheniya, 1980 [Влахов, Сергей, Флорин, Сидер. Непереводимое в переводе. Москва: Международные отношения, 1980].

Yelistratov,Vladimir S. Tolkovyy slovar'russkogo slenga. Moskva: AST-Press Kniga, 2005 [Елистратов, Владимир С. Толковый словарь русского сленга. Москва: АСТ-Пресс Книга, 2005].

Zugumov, Zaur M. Russkoyazychnyy zhargon. Istoriko-etimologicheskiy tolkovyy slovar' prestupnogo mira. Moskva: Knizhnyy mir, 2018 [Зугумов, Заур М. Русскоязычный жаргон. Историко-этимологический толковый словарь преступного мира. Москва: Книжный мир, 2018].

Żmigrodzki, Piotr. Ed. Wielki słownik języka polskiego <https://wsjp.pl/index. php?pwh $=0>$. 